\title{
Absence of endogenous interleukin 10 enhances early stress response during post-ischaemic injury in mice intestine
}

\author{
B Zingarelli, Z Yang, P W Hake, A Denenberg, H R Wong
}

Abstract

Background-Interleukin 10 (IL-10) exerts a wide spectrum of regulatory activities in immune and inflammatory responses.

Aims-The aim of this study was to investigate the role of endogenous IL-10 on modulation of the early inflammatory response after splanchnic ischaemia and reperfusion.

Methods-Intestinal damage was induced by clamping the superior mesenteric artery and the coeliac trunk for 45 minutes followed by reperfusion in IL-10 deficient mice $\left(\mathrm{IL}-10^{-1-}\right)$ and wild-type controls.

Results-IL-10 ${ }^{-1-}$ mice experienced a higher rate of mortality and more severe tissue injury compared with wild-type mice subjected to ischaemia and reperfusion. Splanchnic injury was characterised by massive epithelial haemorrhagic necrosis, upregulation of P-selectin and

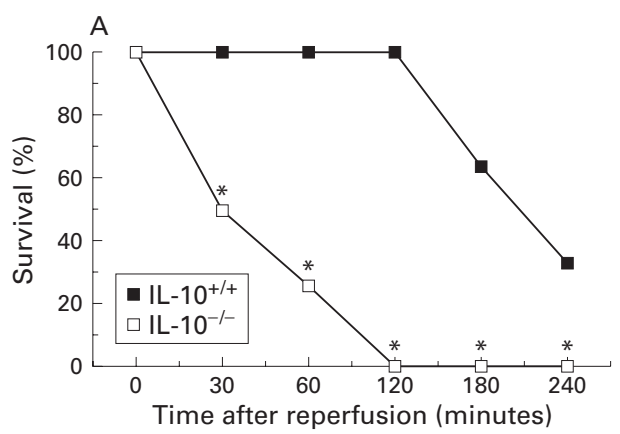

Children's Hospital Medical Center, Division of Critical Care, 3333 Burnet Avenue, Cincinnati, Ohio 45229, USA

B Zingarelli

Z Yang

P W Hake

A Denenberg

H R Wong

Correspondence to: Dr B Zingarelli.

bzingarelli@chmcc.org.

Accepted for publication 5 December 2000

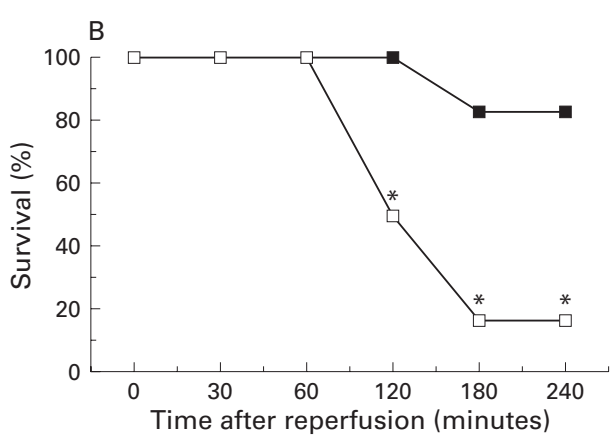

Figure 1 Survival is significantly improved in interleukin $10(\text { IL-10) })^{++}$mice subjected to splanchnic ischaemia and reperfusion in comparison with the high mortality rate of $I L-10^{-/ 2}$ mice. (A) Survival was monitored for four hours after severe reperfusion injury was induced by clamping the superior mesenteric artery and coeliac trunk for 45 minutes. (B) Survival was monitored for four hours after a mild reperfusion injury was induced by clamping only the superior mesenteric artery for 45 minutes. Each point represents percentage of survivors ( $n=12$ animals for each group). ${ }^{\star}$ Significantly different from $I L-10^{+/+}$mice $(p<0.05)$. intercellular adhesion molecule 1 , and neutrophil infiltration. The degree of oxidative and nitrosative damage was significantly higher in $\mathrm{IL}-10^{-1-}$ mice than in wild-type littermates, as indicated by elevated malondialdehyde levels and formation of nitrotyrosine. Plasma levels of the proinflammatory cytokines tumour necrosis factor $\alpha$ and interleukin 6 were also greatly enhanced in comparison with wild-type mice. These events were preceded by increased immunostaining and activity of the stress regulated c-Jun $\mathbf{N H}_{2}$ terminal kinase and activation of the transcription factor activator protein 1 in the cellular nuclei of damaged tissue.

Conclusions-These data demonstrate that endogenous IL-10 exerts an antiinflammatory role during reperfusion injury, possibly by regulating early stress related genetic response, adhesion molecule expression, neutrophil recruitment, and subsequent cytokine and oxidant generation.

(Gut 2001;48:610-622)

Keywords: splanchnic tissue; activator protein 1; adhesion molecules; interleukin 6; c-Jun $\mathrm{NH}_{2}$ terminal kinase; tumour necrosis factor $\alpha$

Acute mesenteric ischaemia followed by reperfusion is a grave condition resulting from vascular diseases, haemorrhage, or trauma, and characterised by local and systemic derangement with a high morbidity and mortality despite intensive care. ${ }^{1}$ Potential mechanisms causing the development and progression of reperfusion injury include polymorphonuclear neutrophil adhesion, activation, and sequestration, release of proinflammatory cytokines, and reactive oxygen and nitrogen species. ${ }^{2-4}$ Current evidence also suggests that oxidative stress during reperfusion represents an important signal for expression of c-Jun $\mathrm{NH}_{2}$ terminal kinase (JNK1). This stress regulated protein relays signals from the oxidant extracellular stimuli to the cell nucleus leading to activation of transcription factors, such as activator protein 1 (AP-1), and adaptive modifications of the damaged cells such as the early process of inflammation and cellular death by apoptosis. ${ }^{5-8}$

Abbreviations used in this paper: AP-1, activator protein 1; ICAM-1, intercellular adhesion molecule 1; IL-6, interleukin 6; IL-10, interleukin 10; JNK1; c-Jun $\mathrm{NH}_{2}$ terminal kinase; TNF- $\alpha$, tumour necrosis factor $\alpha$; GST, glutathione-S-transferase; EMSA, electrophoretic mobility shift assays. 

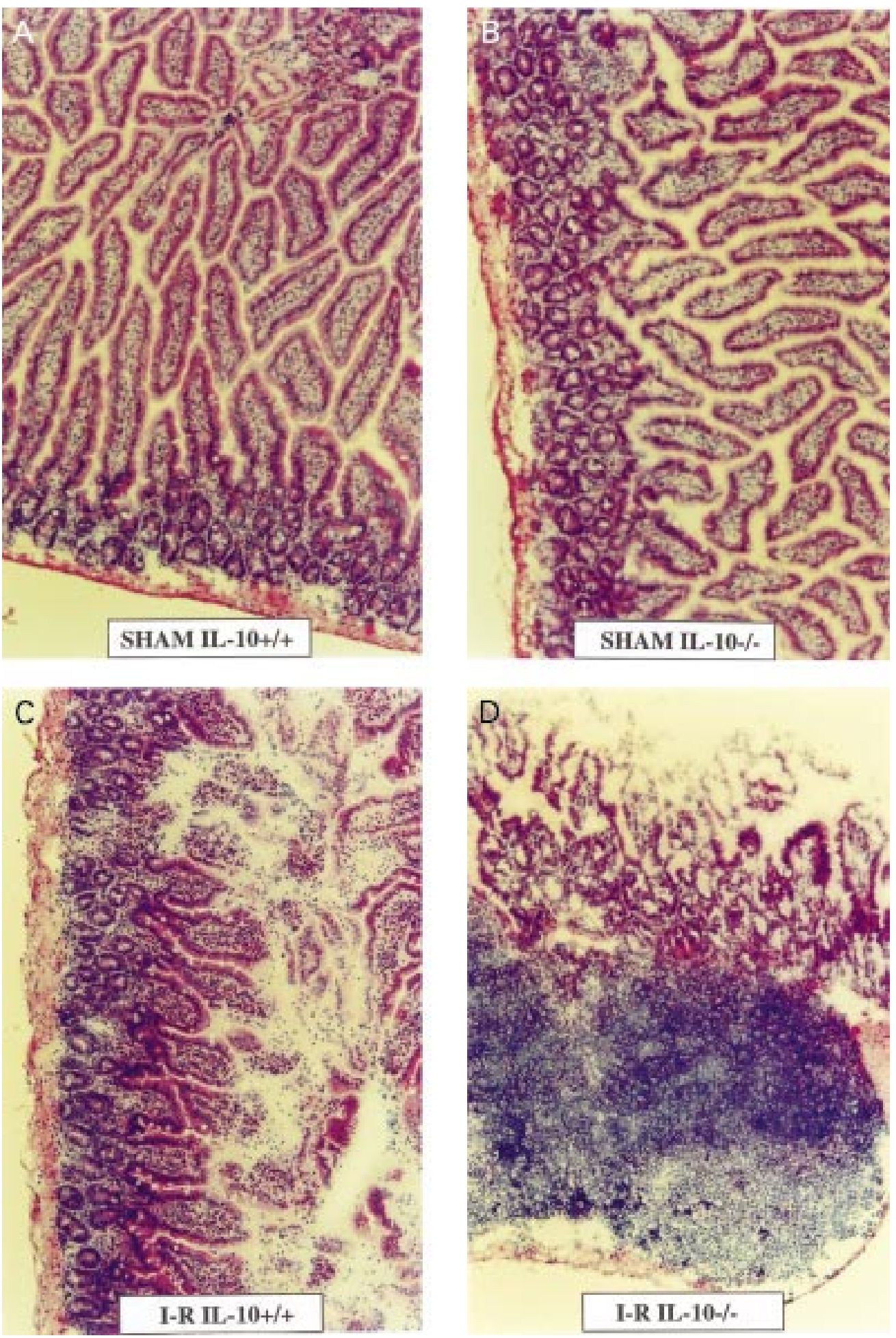

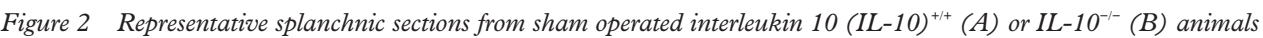
showed normal tissue structure. Following 45 minutes of occlusion and 45 minutes of reperfusion of the superior mesenteric

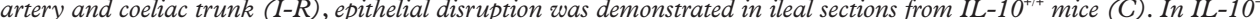
mice subjected to I-R, the splanchnic architecture appeared markedly altered, characterised by the appearance of extensive necrosis, haemorrhage, and neutrophil infiltrate (D). Magnification $\times 100$. A similar pattern was seen in 5-6 different tissue sections in each experimental group.

During the inflammatory reaction, antiinflammatory cytokines are also produced and tend to modulate the inflammatory process. Interleukin 10 (IL-10) is a potent antiinflammatory cytokine that inhibits the synthesis of the major proinflammatory cytokines and chemokines, upregulates humoral immune responses, and attenuates cell mediated immune reactions. ${ }^{9}$ Because of its properties, IL-10 has the ability to modulate several infectious, immune, and inflammatory diseases. It has been demonstrated that administration of exogenous 

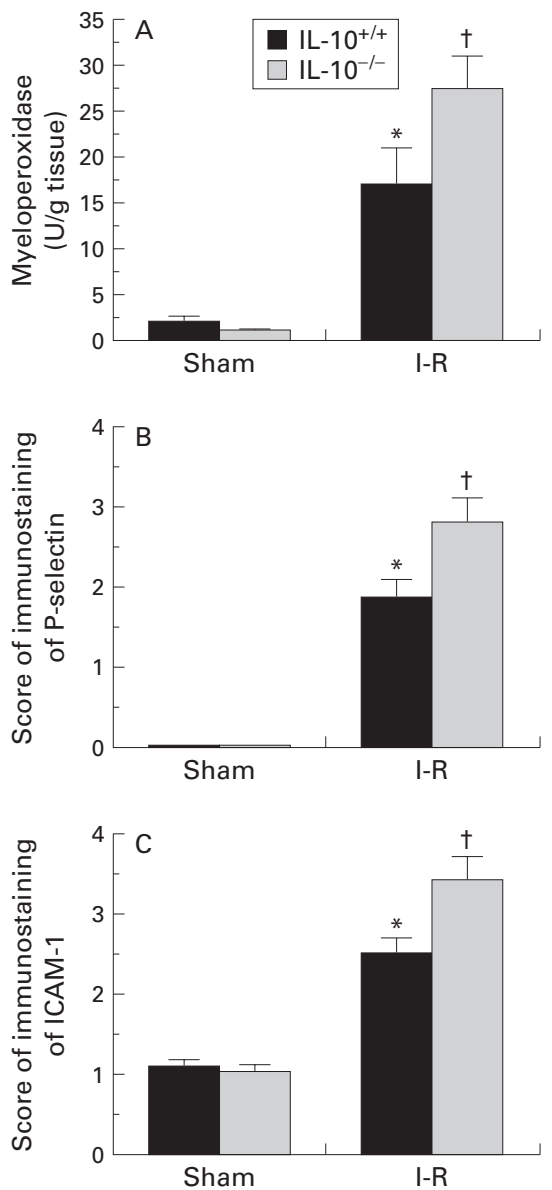

Figure 3 Effect of genetic absence of interleukin 10 (IL-10) on myeloperoxidase activity $(A)$, score of immunostaining for $P$-selectin $(B)$, and score of immunostaining for intercellular adhesion molecule 1 (ICAM-1) (C). Tissue myeloperoxidase activity was enhanced together with increased staining for P-selectin and ICAM-1 after reperfusion in $I L-10^{+/+}$mice subjected to splanchnic ischaemia and reperfusion (I-R). In IL-10 mice subjected to splanchnic injury, levels of

myeloperoxidase, and staining for P-selectin and ICAM-1 were significantly higher compared with $I L-10^{+/+}$animals $\left({ }^{\star} p<0.05\right.$ v respective sham; $t p<0.05$ v IL-10 $0^{+/+}$mice). Each point is mean (SEM) of six animals in each group.

IL-10 improves brain injury, ${ }^{10} 11$ affords cardioprotective effects in animals subjected to myocardial ischaemia and reperfusion, ${ }^{12}$ and prevents lethality in experimental endotoxaemia. ${ }^{13}$ In contrast, administration of antibodies raised against IL-10 exacerbates post-ischaemic renal injury, inflammation, and apoptosis, ${ }^{14}$ whereas genetic deficiency of IL-10 renders mice prone to spontaneous colitis ${ }^{15}$ and more susceptible to develop a severe bacterial granulomatous pneumonitis. ${ }^{16}$

The purpose of this study was to investigate the role of endogenous IL-10 in a murine model of splanchnic ischaemia and reperfusion injury. To address this question, release of proinflammatory cytokines and the neutrophilendothelial interaction were evaluated. Nitrotyrosine formation and tissue levels of malondialdehyde were determined as an index of nitrosative and oxidative stress, respectively. Furthermore, we investigated if genetic absence of IL-10 affects splanchnic expression and activity of JNK 1 and subsequent activation of AP-1. We observed that absence of the IL-10 gene exaggerated the acute splanchnic injury induced by ischaemia and reperfusion, whereas maintenance of endogenous IL-10 production significantly attenuated the injury, indicating that the cytokine may mediate important features of mesenteric infarction.

\section{Methods}

ANIMALS

The investigation conformed to the Guide for the Care and Use of Laboratory Animals published by the US National Institutes of Health (NIH Publication No 85-23 revised 1985) and was approved by the Institutional Animal Care and Use Committee. C57BL/10 mice (4-5 weeks old, 20-22 g) with a targeted disruption of the IL-10 gene (IL- $10^{-/-}$) and littermate wild-type controls (IL- $10^{+/+}$) were purchased from Jackson Laboratories (Bar Harbor, Maine, USA).

SPLANCHNIC ISCHAEMIA AND REPERFUSION Animals were anaesthetised with thiopentone sodium ( $4 \mathrm{mg} / \mathrm{ml}, 10 \mu \mathrm{l} / \mathrm{g}$ wt of mouse) and were placed in a supine position with their paws taped to the operating table. After midline laparotomy, the coeliac trunk and superior mesenteric artery were isolated near their aortic origins. During this procedure, the intestinal tract was maintained at $37^{\circ} \mathrm{C}$ by placing it between gauze pads soaked with warmed $0.9 \% \mathrm{NaCl}$ solution. Splanchnic artery occlusion was performed by clamping both arteries for 45 minutes, as previously described. ${ }^{2}$ After this period of occlusion, reperfusion was induced by removing the clamps. In a group of animals, survival was monitored for four hours. Other groups of mice were sacrificed at $5,15,30$, or 45 minutes after reperfusion and tissues were rapidly removed for evaluation of JNK1 and AP-1 activation. Quantification of bowel injury, and other immunohistochemical and biochemical studies were performed on ileal samples obtained at $45 \mathrm{~min}$ utes after reperfusion. Blood samples for cytokine measurement were obtained by cardiac puncture at 45 minutes after reperfusion. A group of mice underwent the above surgical procedure with the exception of occlusion and reperfusion of the splanchnic arteries and served as a sham control group.

MEASUREMENT OF CYTOKINE PLASMA LEVELS Plasma levels of tumour necrosis factor $\alpha$ (TNF- $\alpha$ ), interleukin 6 (IL-6), and IL-10 were evaluated by commercially available solid phase sandwich ELISA kits (R\&D Systems, Minneapolis, Minnesota, USA) using the protocol recommended by the manufacture. The sensitivity of these ELISA kits was less than $0.05 \mathrm{pg} / \mathrm{ml}$.

\section{HISTOPATHOLOGICAL ANALYSIS AND DAMAGE} SCORE

Tissues were fixed in $4 \%$ paraformaldehyde and embedded in paraffin. Sections were stained with haematoxylin and eosin for histological evaluation of tissue damage. In order to obtain a quantitative estimation of ileal damage, sections ( $n=6$ for each animal) were scored by two independent observers blinded to the 

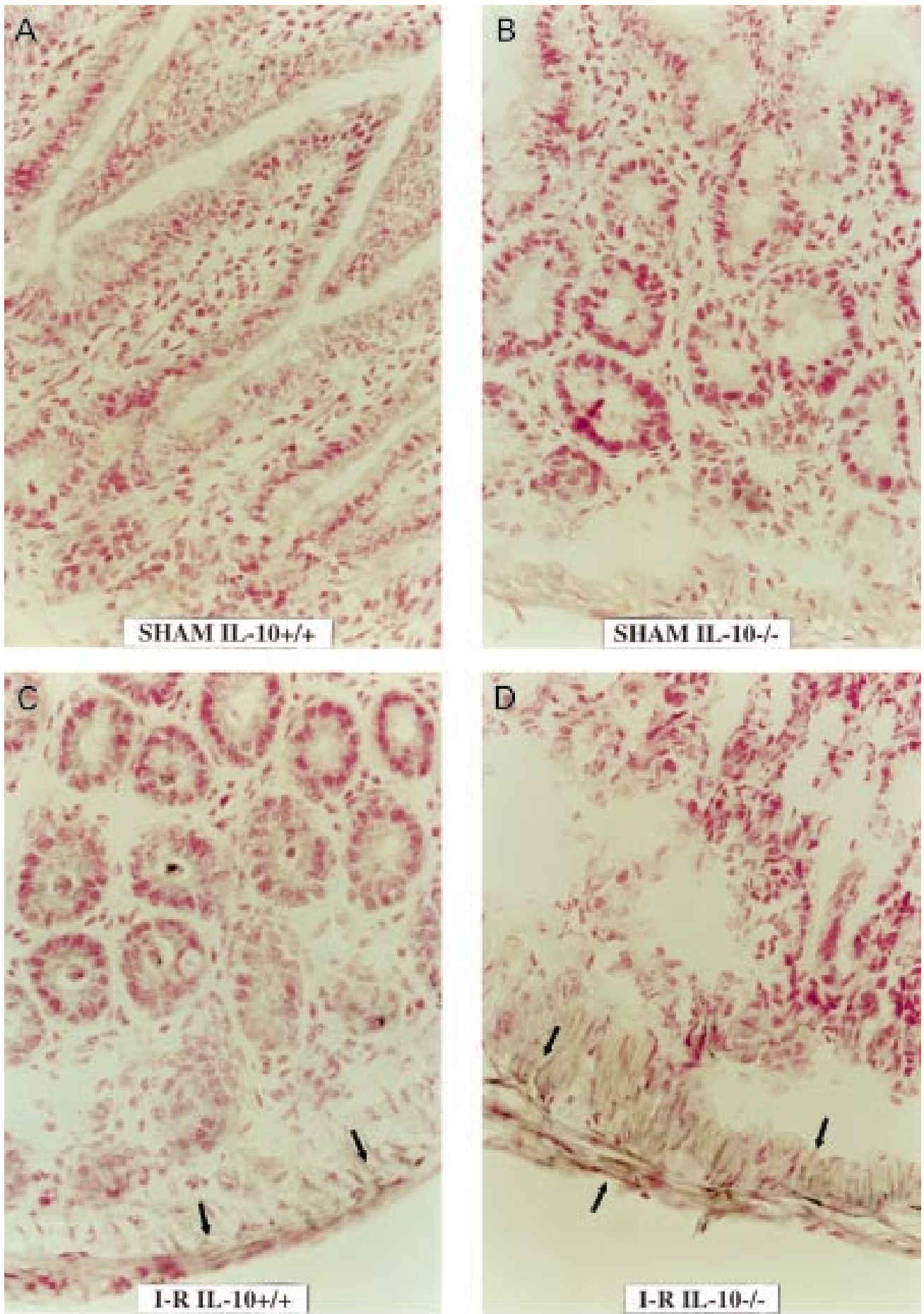

Figure 4 Representative immunostaining of intestinal expression of P-selectin. Sections from the small intestine of sham operated interleukin $10(I L-10)^{+/+}(A)$ or IL-10 $0^{-1-}$ animals (B) had no P-selectin staining. Splanchnic ischaemia and reperfusion (I-R) in IL-1 $0^{+1+}$ animals induced the appearance of positive staining for P-selectin (arrows) along the endothelium in the small vessels of the lamina propria $(C)$. In IL-10 $0^{-1}$ mice subjected to I-R, immunostaining for P-selectin was markedly enhanced (D). Magnification $\times 400$. A similar pattern was seen in $n=5-6$ different tissue sections in each experimental group.

experimental protocol. The following morphological criteria were considered: score 0 , no damage; score 1 (mild), focal epithelial oedema and necrosis; score 2 (moderate), diffuse swelling and necrosis of the villi; score 3 (severe), necrosis with the presence of neutrophil infiltrate in the submucosa; and score 4 (highly severe), widespread necrosis with massive neutrophil infiltrate and haemorrhage.
MEASUREMENT OF MYELOPEROXIDASE ACTIVITY Myeloperoxidase activity was determined as an index of neutrophil accumulation, as previously described. ${ }^{17}$ Samples of small intestine, collected 45 minutes after reperfusion, were homogenised in a solution containing $0.5 \%$ hexa-decyltrimethyl-ammonium bromide dissolved in 10 $\mathrm{mM}$ potassium phosphate buffer $(\mathrm{pH} 7)$ and centrifuged for 30 minutes at $20000 \mathrm{~g}$ at $4^{\circ} \mathrm{C}$. 

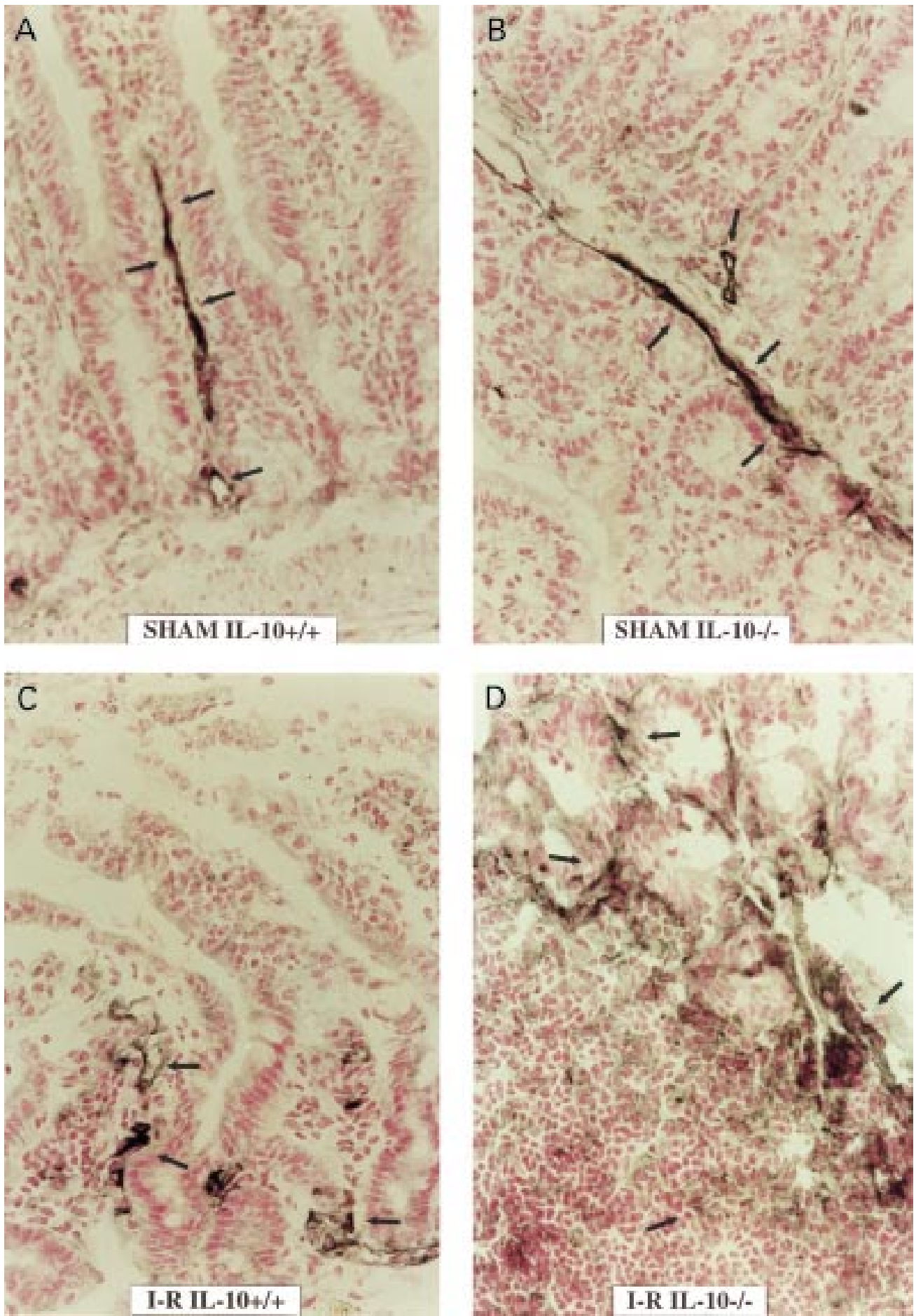

Figure 5 Representative immunostaining of intestinal expression of intercellular adhesion molecule 1 (ICAM-1). Control tissues from sham operated interleukin $10(I L-10)^{+/+}(A)$ or IL-10 $0^{-1-}$ animals (B) showed a dark brown staining (arrows) of endothelium of blood vessels indicating the presence of constitutive ICAM-1 protein. Splanchnic ischaemia and

reperfusion (I-R) in $I L-10^{+/+}$induced an increase in positive staining for ICAM-1 along the endothelial vascular wall and

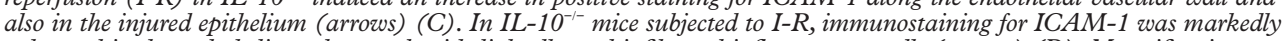
enhanced in the endothelium, damaged epithelial cells, and infiltrated inflammatory cells (arrows) (D). Magnification $\times 400$. A similar pattern was seen in $n=5-6$ different tissue sections in each experimental group. ICAM- 1 was identified by immunohistochemical localisation with specific antibody labelling using an avidin-biotin peroxidase technique.

An aliquot of the supernatant was allowed to react with a solution of tetra-methyl-benzidine (1.6 $\mathrm{mM}$ ) and $0.1 \mathrm{mM} \mathrm{H}_{2} \mathrm{O}_{2}$. The rate of change in absorbance was measured by spectrophotometry at $650 \mathrm{~nm}$. Myeloperoxidase activity was defined as the quantity of enzyme degrading 1 $\mu \mathrm{mol}$ of hydrogen peroxide/minute at $37^{\circ} \mathrm{C}$ and expressed in units per gram weight tissue.
IMMUNOHISTOCHEMICAL STAINING FOR P-SELECTIN AND ICAM-1

P-selectin and intercellular adhesion molecule 1 (ICAM-1) expression was evaluated in ileal sections by immunohistochemistry. ${ }^{18}$ Frozen sections $5 \mu \mathrm{m}$ thick were fixed in $4 \%$ paraformaldehyde and incubated in $2 \%$ normal rat serum (for P-selectin evaluation) or hamster serum (for 

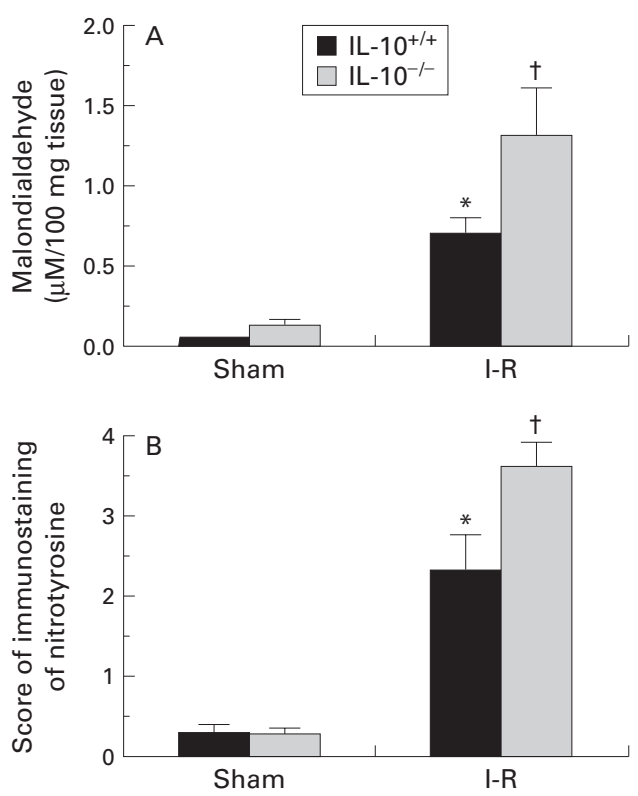

Figure 6 Effect of genetic absence of interleukin 10 (IL-10) on tissue levels of malondialdehyde $(A)$ and score of immunostaining for nitrotyrosine (B). Tissue malondialdehyde was enhanced together with increased staining for nitrotyrosine after reperfusion in $I L-10^{+/+}$mice subjected to splanchnic ischaemia (I-R). In IL-10 $0^{-/-}$mice subjected to splanchnic injury, levels of malondialdehyde and staining for nitrotyrosine were significantly higher compared with $I L-10^{+/+}$animals $\left({ }^{*} p<0.05 v\right.$ respective sham; $t p<0.05 v I L-10^{+++}$mice). Each point is the mean (SEM) of six animals in each group.

ICAM-1) for two hours to minimise nonspecific adsorption. Sections were then incubated overnight at $4^{\circ} \mathrm{C}$ with monoclonal biotinylated antibodies directed at P-selectin (rat antimouse CD62P) or ICAM-1 (hamster antimouse CD54) at a 1:500 dilution. Controls included buffer alone or non-specific purified IgG. Antibody binding sites were visualised with an avidin-biotin peroxidase complex immunoperoxidase technique (Vector Laboratories, Burlingame, California, USA) using diaminobenzidine. To quantitate the degree of $\mathrm{P}$-selectin staining on endothelial wall, a $0-4$ grading system was used: 0 , no staining; $1-3$, increasing degrees of intermediate staining; and 4, extensive staining. To quantitate the degree of ICAM-1 staining, a 0-4 grading system was used: 0 , no staining; 1 , constitutive presence of staining along the endothelial wall; $2-3$, increasing degrees of intermediate staining along the endothelial wall; and 4, increased staining along the endothelial wall and presence of staining on epithelial cells. In each experimental group, $\mathrm{n}=5-6$ sections were evaluated by two independent observers blinded to the experimental protocol.

MEASUREMENT OF ILEAL MALONDIALDEHYDE Tissue levels of malondialdehyde were determined as an index of lipid peroxidation. ${ }^{19}$ Tissue samples were taken 45 minutes after reperfusion and homogenised in $1.15 \% \mathrm{KCl}$ solution. An aliquot $(100 \mu \mathrm{l})$ of the homogenate was added to a reaction mixture containing $200 \mu \mathrm{l}$ of $8.1 \%$ SDS, $1500 \mu \mathrm{l}$ of $20 \%$ acetic acid (pH 3.5), 1500 $\mu \mathrm{l}$ of $0.8 \%$ thiobarbituric acid, and $700 \mu \mathrm{l}$ distilled water. Samples were then boiled for one hour at $95^{\circ} \mathrm{C}$ and centrifuged at $3000 \mathrm{~g}$ for 10 minutes. Absorbance of the supernatant was measured by spectrophotometry at $532 \mathrm{~nm}$ and compared with a standard curve obtained with 1,1,3,3-tetramethoxypropane. Data were expressed as $\mu \mathrm{M}$ per $100 \mathrm{mg}$ weight of tissue.

IMMUNOHISTOCHEMICAL STAINING FOR NITROTYROSINE AND JNK1

Tyrosine nitration and JNK1 expression were detected in ileal sections by immunohistochemistry. ${ }^{6}{ }^{18}$ Frozen sections $5 \mu \mathrm{m}$ thick were fixed in $4 \%$ paraformaldehyde and incubated for two hours with a blocking solution $(0.1 \mathrm{M}$ phosphate buffered saline containing $0.1 \%$ Triton $\mathrm{X}$ 100 and $2 \%$ normal goat serum) to minimise non-specific adsorption. Sections were then incubated overnight with a 1:500 dilution of primary antinitrotyrosine antibody, primary anti-JNK1 antibody, or with control solutions. Controls included buffer alone or non-specific purified rabbit IgG. Specific labelling was detected by incubating for 30 minutes with a biotin conjugated goat antirabbit IgG and amplified with avidin-biotin peroxidase complex (Vectastain Elite ABC kit; Vector Laboratories) after quenching endogenous peroxidase with $0.3 \% \mathrm{H}_{2} \mathrm{O}_{2}$ in $100 \%$ methanol for $15 \mathrm{~min}-$ utes. Diaminobenzidine was used as a chromogen. To quantitate the degree of nitrotyrosine or JNK1 staining, a 0-4 grading system was used: 0 , no staining; $1-3$, increasing degrees of intermediate staining; and 4 , extensive staining. In each experimental group, $n=5-6$ sections were evaluated by two independent observers blinded to the experimental protocol.

\section{ASSAY OF JNK1 ACTIVITY}

JNK1 activity was determined by immune complex kinase assay and was estimated as the ability to phosphorylate glutathione-S-transferase (GST)-c-Jun. ${ }^{6}$ Tissue samples were homogenised with a Polytron homogeniser in a buffer containing $0.32 \mathrm{M}$ sucrose, $10 \mathrm{mM}$ Tris $\mathrm{HCl}$, pH 7.4, 1 mM EGTA, 2 mM EDTA, $5 \mathrm{mM}$ $\mathrm{NaN}_{3}, 10 \mathrm{mM} \quad \beta$-mercaptoethanol, $20 \mu \mathrm{M}$ leupeptin, $0.15 \mu \mathrm{M}$ pepstatin $\mathrm{A}, 0.2 \mathrm{mM}$ phenylmethanesulphonyl fluoride, $50 \mathrm{mM} \mathrm{NaF}$, $1 \mathrm{mM}$ sodium orthovanadate, and $0.4 \mathrm{nM}$ microcystin. The homogenates were centrifuged (1000 g, 10 minutes) and the pellets were solubilised in Triton buffer ( $1 \%$ Triton X-100, 150 $\mathrm{mM} \mathrm{NaCl}, 10 \mathrm{mM}$ Tris $\mathrm{HCl}, \mathrm{pH} 7.4,1 \mathrm{mM}$ EGTA, $1 \mathrm{mM}$ EDTA, $0.2 \mathrm{mM}$ sodium orthovanadate, $20 \mu \mathrm{M}$ leupeptin $\mathrm{A}$, and $0.2 \mathrm{mM}$ phenylmethanesulphonyl fluoride). The lysates were centrifuged $\left(15000 \mathrm{~g}, 30\right.$ minutes, $\left.4^{\circ} \mathrm{C}\right)$ and the supernatant (nuclear extract) was collected. After immunoprecipitation with specific antibody directed to JNK1, the immunoprecipitate was incubated for 30 minutes at $30^{\circ} \mathrm{C}$ in $40 \mu \mathrm{l}$ of reaction buffer containing 25 mmol/1 HEPES ( $\mathrm{pH} 7.6$ ), $20 \mathrm{mM} \mathrm{MgCl}_{2}, 20$ $\mathrm{mM}$ glycerolphosphate, $0.1 \mathrm{mM}$ sodium orthovanadate, $2 \mathrm{mM}$ dithiothreitol, $25 \mu \mathrm{M}$ ATP, and $5 \mu \mathrm{Ci}$ of $\left[\gamma^{32} \mathrm{P}\right]$ ATP. GST-c-Jun (1-79) $(1$ $\mu \mathrm{g})$ was used as substrate. Reaction products were separated by sodium dodecyl sulphatepolyacrylamide gel electrophoresis and visualised by autoradiography. Densitometric analysis 

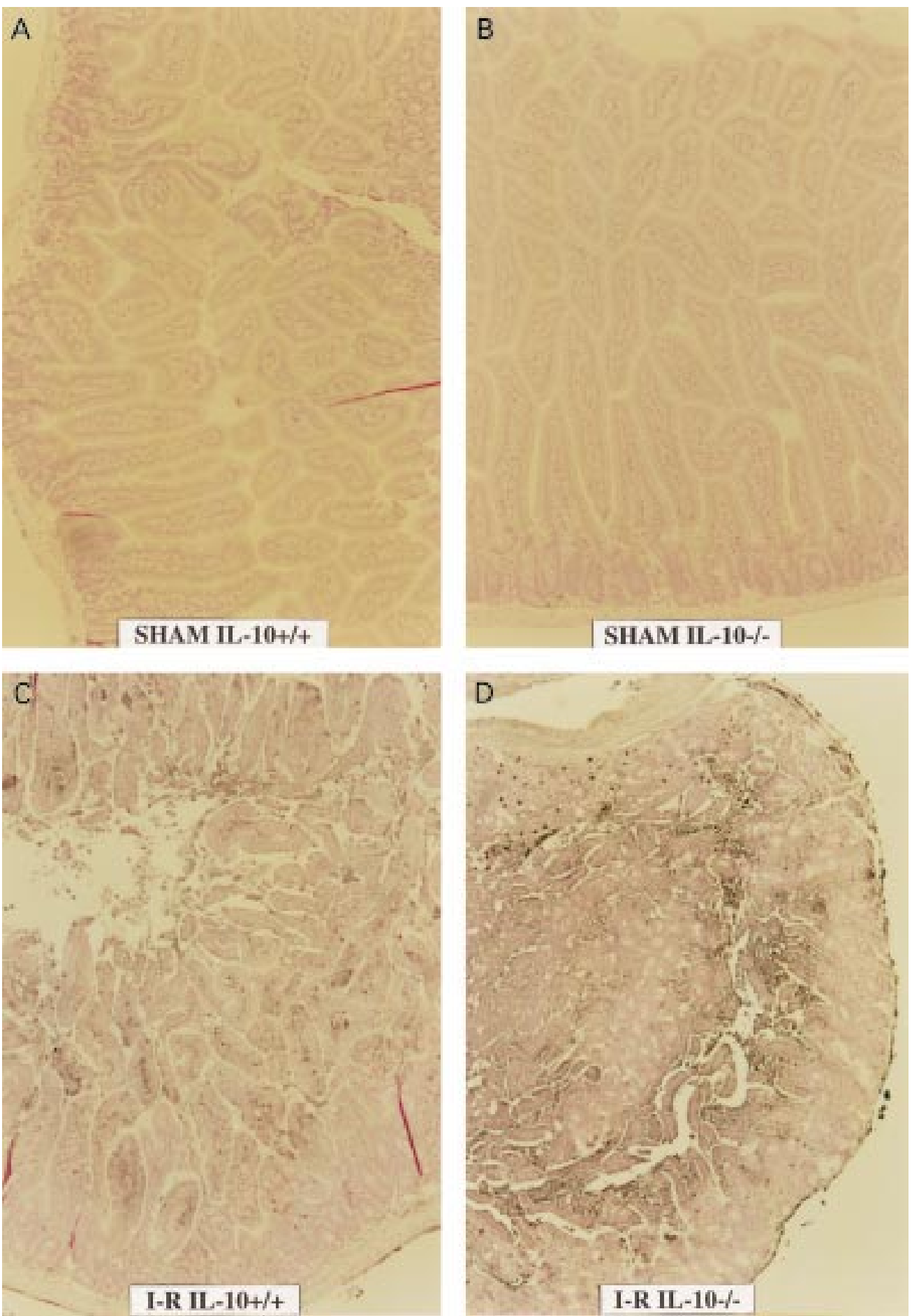

Figure 7 Representative immunostaining of intestinal nitrotyrosine. Immunohistochemical staining of nitrotyrosine was considered as a marker of nitrosative stress. In sections of small intestine from sham operated interleukin 10 (IL-10) ${ }^{+/+}(A)$ or IL-10 $0^{-1-}$ animals (B), weak non-specific or no staining for nitrotyrosine was found. In the reperfused splanchnic tissue after ischaemia $(S A O)$ of $I L-10^{+/+}$animals a diffuse dark staining was localised in the necrotic area $(C)$. In $I L-10^{-/-}$mice subjected to $S A O$, immunostaining for nitrotyrosine was markedly enhanced (D). Magnification $\times 100$. A similar pattern was seen in $n=5-6$ different tissue sections in each experimental group.

was performed using ImageQuant (Molecular Dynamics).

ELECTROPHORETIC MOBILITY SHIFT ASSAY

Electrophoretic mobility shift assays (EMSA) were performed as previously described. $.^{20} \mathrm{Oli}-$ gonucleotide probes corresponding to an AP-1 consensus sequence (5'-CGC TTG ATG ACT CAG CCG GAA-3') were labelled with $\gamma-\left[{ }^{32} \mathrm{P}\right]$ ATP using T4 polynucleotide kinase (Gibco, BRL, Rockville, Maryland, USA) and purified in Bio-Spin chromatography columns (BioRad; Hercules, California, USA). Nuclear protein $(10 \mathrm{~g})$ was preincubated with EMSA buffer (12 mM HEPES, pH 7.9, $4 \mathrm{mM}$ Tris $\mathrm{HCl}, \mathrm{pH} 7.9,25 \mathrm{mM} \mathrm{KCl}, 5 \mathrm{mM} \mathrm{MgCl}_{2}, 1$ $\mathrm{mM}$ EDTA, $1 \mathrm{mM}$ DTT, $50 \mathrm{ng} / \mathrm{ml}$ poly $[\mathrm{d}(\mathrm{I}-\mathrm{C})], \quad 12 \%$ glycerol $\mathrm{v} / \mathrm{v}$, and $0.2 \mathrm{mM}$ 

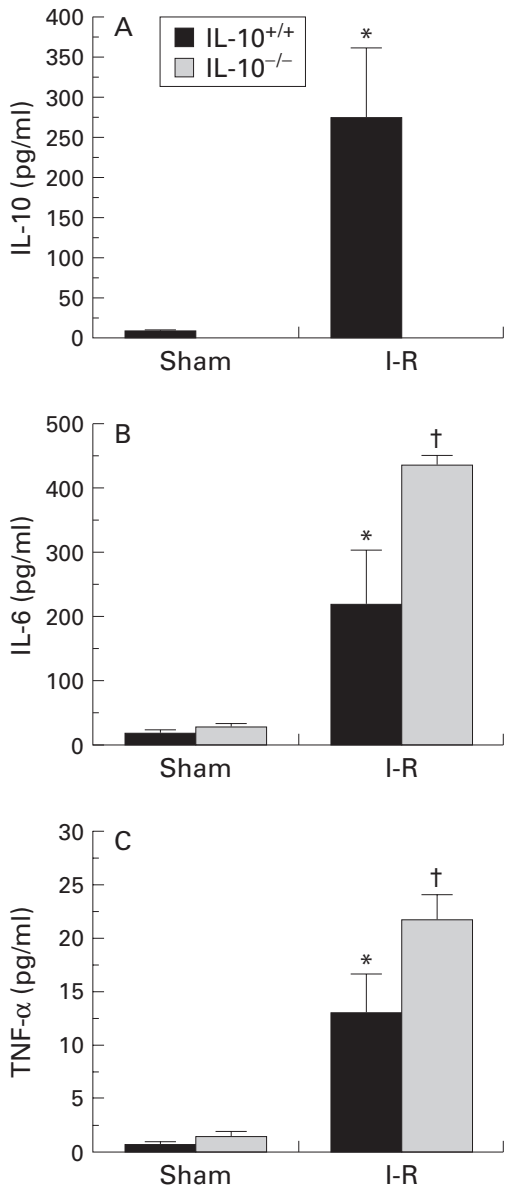

Figure 8 Effect of genetic absence of interleukin 10 (IL-10) on IL-10, tumour necrosis factor a (TNF-a), and interleukin 6 (IL-6) production after splanchnic ischaemia and reperfusion (I-R). Each point is the mean (SEM) of five animals in each group $\left({ }^{\star} p<0.05 v\right.$ respective sham; $t p<0.05$ v IL-10 $0^{+/+}$mice).

PMSF) on ice for 10 minutes before addition of the radiolabelled oligonucleotide for an additional 10 minutes. Protein-nucleic acid complexes were resolved using a nondenaturing polyacrylamide gel consisting of $5 \%$ acrylamide (29:1 ratio of acrylamide:bisacrylamide) and run in $0.5 \times \mathrm{TBE}(45 \mathrm{mM}$ Tris $\mathrm{HCl}, 45 \mathrm{mM}$ boric acid, $1 \mathrm{mM}$ EDTA) for one hour at constant current $(30 \mathrm{~mA})$. Gels were transferred to Whatman $3 \mathrm{M}$ paper, dried under a vacuum at $80^{\circ} \mathrm{C}$ for one hour, and exposed to photographic film at $-70^{\circ} \mathrm{C}$ with an intensifying screen. Densitometric analysis was performed using ImageQuant (Molecular Dynamics).

MATERIALS

Primary antinitrotyrosine antibody was purchased by Upstate Biotech (Saranac Lake, New York, USA). Primary monoclonal ICAM-1 (CD54) or P-selectin (CD62P) antibodies for immunohistochemistry were purchased from Pharmingen (San Diego, California, USA). The primary antibodies directed at JNK1 and oligonucleotide probe for AP-1 consensus were obtained from Santa Cruz Biotechnology, Inc. (Santa Cruz, California, USA). Hamster and rat serums were purchased from Jackson ImmunoResearch Laboratories (West Grove,
Pennsylvania, USA). Reagents, and secondary and non-specific IgG antibodies for immunohistochemical analysis were from Vector Laboratories Inc. All other chemicals were from Sigma/Aldrich (St Louis, Missouri, USA).

STATISTICAL ANALYSIS

All values in the figures and text are expressed as mean (SEM) of $n$ observations, where $n$ represents the number of mice ( $n=6$ animals in each group). Results were examined by analysis of variance followed by Bonferroni's correction post hoc $t$ test. Survival data $(\mathrm{n}=12$ animals in each group) were analysed by the $\chi^{2}$ test. Statistical analysis of scores was performed using the Mann-Whitney $U$ test. $p$ values less than 0.05 were considered significant.

\section{Results}

ABSENCE OF IL-10 INCREASES MORTALITY AFTER SPLANCHNIC ISCHAEMIA AND REPERFUSION

To imitate the clinical scenario of mesenteric infarction, mice were subjected to 45 minutes of occlusion followed by reperfusion of the superior mesenteric artery and coeliac trunk, which are the major blood suppliers of the intestine. In pilot studies, mice lacking a functional gene for IL-10 exhibited a high rate of mortality and $83 \%$ of animals were dead within 45-60 minutes after reperfusion. In contrast, wild-type mice- that is, with a functional gene for IL-10-were still alive at 60 minutes after reperfusion (fig $1 \mathrm{~A}$ ). In a second study, we evaluated survival to a less severe model of injury, as obtained by clamping only the superior mesenteric artery for 45 minutes. However, even under this mild condition, mice lacking the IL-10 gene appeared to be more susceptible to death than wild-type controls: $50 \%$ of IL $-10^{-/-}$mice were dead whereas all IL- $10^{+/+}$mice were still alive at two hours after reperfusion (fig $1 \mathrm{~B}$ ).

On the basis of these results, to better highlight the potential importance of IL-10 in the modulation of detrimental reperfusion injury, subsequent experiments were performed in animals subjected to 45 minutes of occlusion of both the superior mesenteric artery and coeliac trunk followed by 45 minutes of reperfusion.

SPLANCHNIC INJURY IS REDUCED IN IL- $10^{+/+}$MICE In sham wild-type and IL- $10^{-/-}$mice, the histological features of the gastrointestinal tract were typical of a normal architecture. In wild-type mice, occlusion and reperfusion of the splanchnic arteries resulted in tissue injury mainly localised in the small intestine, whereas no histological signs of inflammation were observed in the stomach or colon. At histological examination of the reperfused tissue, damage was localised at the villus surface and was associated with infiltration of inflammatory cells and haemorrhage (see fig 2 for representative section). The degree of damage (on a scale of 0-4) averaged 2.63 (0.09). Absence of a functional IL-10 gene in IL-10 $0^{-/-}$mice resulted in significant augmentation of reperfusion injury of previously ischaemic small intestine. The histological features were characterised by widespread disruption of the mucosa, massive 

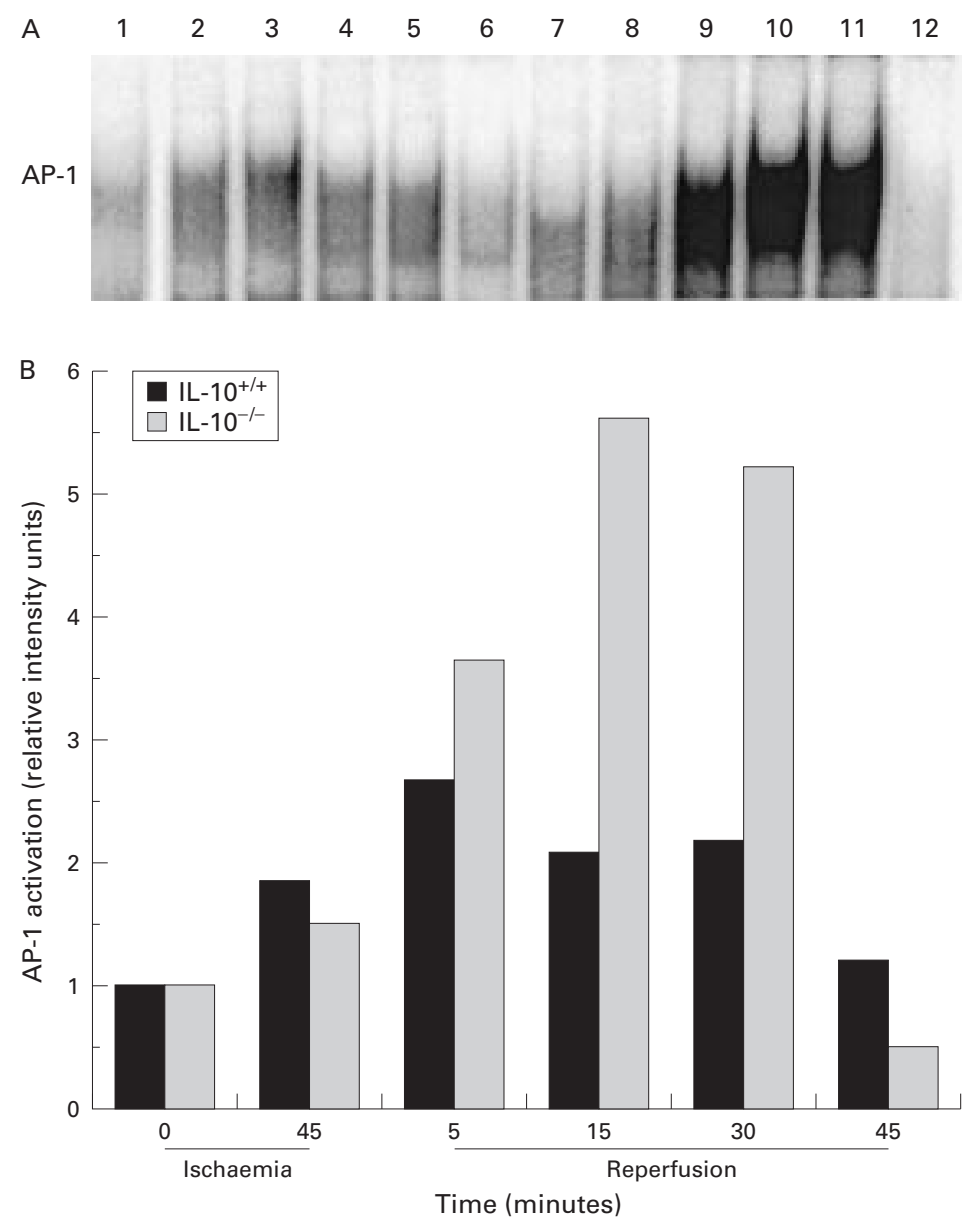

Figure 9 Effect of genetic absence of interleukin 10 (IL-10) on activation of activator protein 1 (AP-1) during splanchnic ischaemia and reperfusion. (A) Representative autoradiograph of electrophoretic mobility shift assay for AP-1. Lane 1 represents intestinal basal DNA binding activity of AP-1 of a wild-type mouse at time 0; lanes 2-3 show slightly increased activity in splanchnic sections from wild-type mice at 45 minutes of ischaemia (lane 2), and at reperfusion at five minutes (lane 3); decline of activity was seen at reperfusion at 15 (lane 4), 30(lane 5), and 45(lane 6) minutes; lane 7 represents

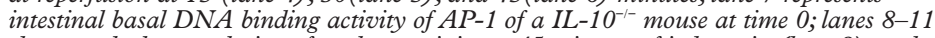
show marked upregulation of nuclear activity at 45 minutes of ischaemia (lane 8), and at reperfusion at five (lane 9), 15 (lane 10), and 30 (lane 11) minutes in $\mathrm{IL}-10^{-1-}$ mice; and decline of activity was seen at 45 minutes of reperfusion (lane 12). (B) Image analysis of activation of AP-1 determined by densitometry from the autoradiograph. Fold increase was calculated versus respective sham value (time 0) set to 1.0. Results are representative of three separate time course experiments.

infiltrate of inflammatory cells, and haemorrhage in the lamina propria, submucosa, and mucosa (see fig 2 for representative section). The damage score for IL-10 $0^{-/-}$mice was significantly increased $(3.47(0.16))$ compared with IL- $10^{+/+}$littermates $(\mathrm{p}<0.001)$.

P-SELECTIN AND ICAM-1 EXPRESSION, AND NEUTROPHIL INFILTRATION IS INCREASED IN IL- $10^{-/-}$MICE

A hallmark of reperfusion injury is accumulation into the injured tissue of neutrophils, which augments the damage to vascular and epithelial cells. ${ }^{4}$ Therefore, we next evaluated the extent of expression of P-selectin and ICAM-1, adhesion molecules involved in the rolling and firm attachment to the endothelium, and transmigration of neutrophils. Assessment of neutrophil infiltration in splanchnic tissue was also performed by measurement of the activity of myeloperoxidase, an enzyme specific to granulocyte lysosomes and therefore directly correlated to the number of neutrophils. Myeloperoxidase activity was significantly elevated after splanchnic ischaemia and reperfusion in IL- $10^{+/+}$mice (fig 3A). Elevation of the enzyme was associated with an increase in immunohistochemical staining for P-selectin and ICAM-1 in the injured splanchnic tissue (figs 4, 5). In IL-10 $0^{-/-}$mice, tissue myeloperoxidase activity, P-selectin, and ICAM-1 immunostaining were markedly increased in comparison with those of IL- $10^{+/+}$animals (figs $3-5)$.

ABSENCE OF ENDOGENOUS IL-10 FAVOURS LIPID PEROXIDATION AND NITROTYROSINE FORMATION Release of free radicals and oxidant molecules during the early period of reperfusion has been suggested to contribute significantly to tissue necrosis and mucosal dysfunction. ${ }^{2-4}$ Splanchnic injury of IL- $10^{+/+}$wild-type mice was characterised by an increase in tissue malondialdehyde, indicative of lipid peroxidation (fig 6A). Furthermore, positive staining for nitrotyrosine, a marker of nitrosative injury, was found on epithelial and infiltrated inflammatory cells in the injured small intestine of IL- $10^{+/+}$mice (figs $6 \mathrm{~B}, 7$ ). Targeted disruption of the IL-10 gene in mice subjected to splanchnic ischaemia and reperfusion exaggerated the formation of malondialdehyde and nitrotyrosine, thus indicating the occurrence of more severe oxidant induced damage (figs 6,7).

ENDOGENOUS IL-10 MODULATES PRODUCTION OF TNF- $\alpha$ AND IL- 6 AFTER SPLANCHNIC ISCHAEMIA AND REPERFUSION

To test if endogenous IL-10 modulates the inflammatory process through regulation of cytokine secretion, we analysed plasma levels of the proinflammatory cytokines TNF- $\alpha$ and IL-6 in IL-10 $0^{-/-}$and wild-type mice. A substantial increase in TNF- $\alpha$, IL- 6 , and IL-10 production was found in $\mathrm{IL}-10^{+/+}$mice after splanchnic ischaemia and reperfusion. Levels of TNF- $\alpha$ and IL- 6 were significantly higher in IL-10 deficient mice in comparison with those of IL- $10^{+/+}$animals (fig 8).

NUCLEAR ACTIVATION OF AP-1 AND EXPRESSION AND ACTIVITY OF JNK1 AFTER SPLANCHNIC ISCHAEMIA AND REPERFUSION IS INCREASED IN THE ABSENCE OF A FUNCTIONAL GENE OF IL-10 To investigate the cellular mechanisms by which endogenous IL-10 may attenuate reperfusion induced injury, we evaluated nuclear activation of AP-1, a transcription factor involved in signal transduction of the inflammatory process. $^{82}$ In $\mathrm{IL}-10^{-/-}$mice, reperfusion after splanchnic ischaemia resulted in early activation of $\mathrm{AP}-1$ with activity reaching a maximum after 15 minutes of reperfusion and declining thereafter. In contrast, in $\mathrm{IL}-10^{+/+}$ mice the reduction in intestinal damage was associated with a reduction of the DNA binding activity of AP-1 (fig 9).

As phosphorylation of components of AP-1, such as c-Jun, by JNK1 represents an important event for stability and activation of the transcription factor AP-1, ${ }^{81}$ we further determined nuclear expression and activity of JNK1. 

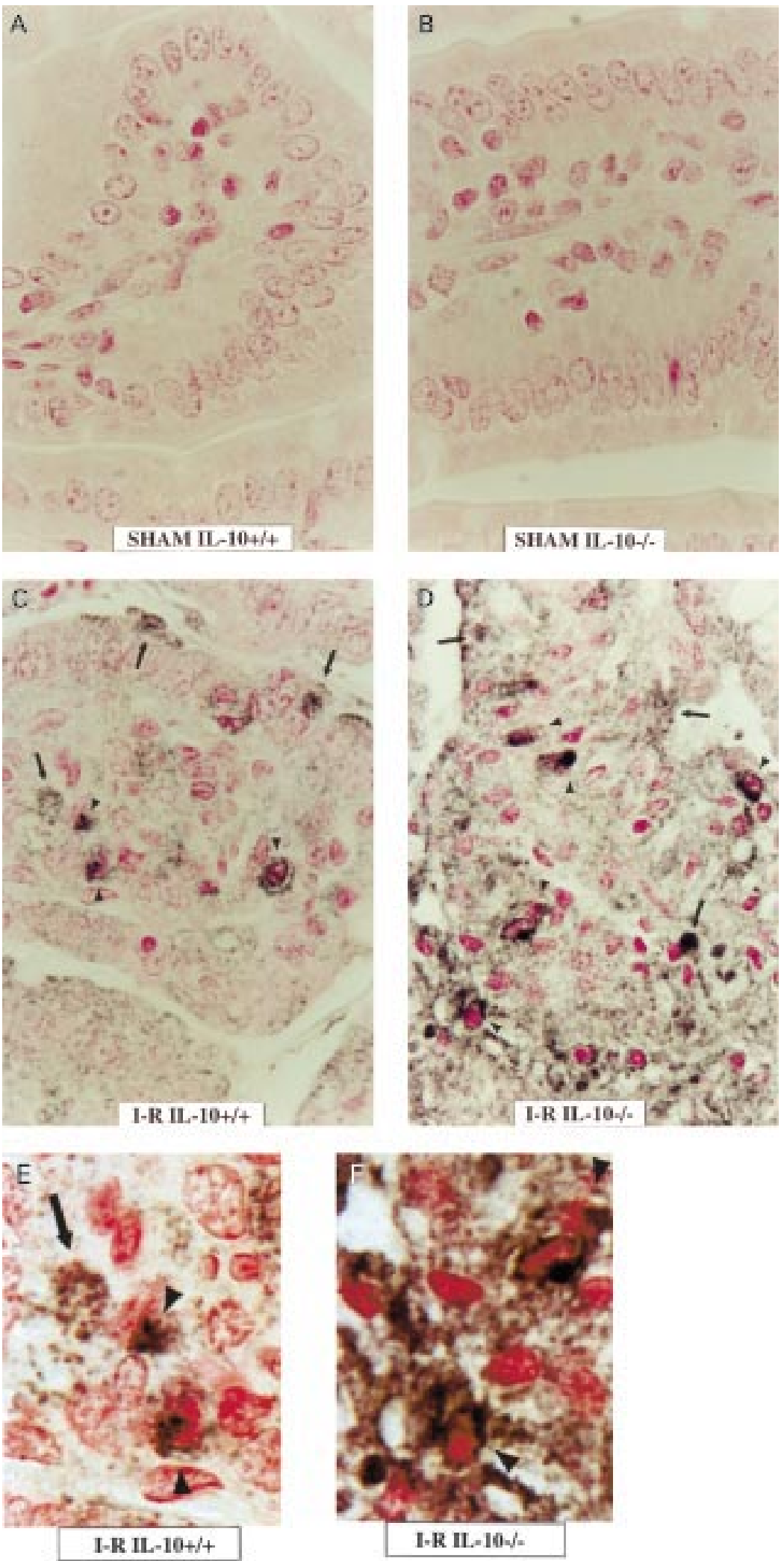

Figure 10 Representative immunostaining of c-fun $\mathrm{NH}_{2}$ terminal kinase ( $(\mathrm{NN} 1)$ after splanchnic ischaemia and

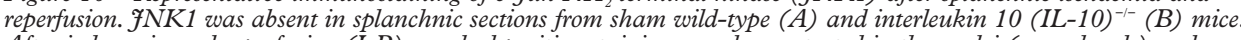
After ischaemia and reperfusion (I-R), marked positive staining was demonstrated in the nuclei (arrowheads) and

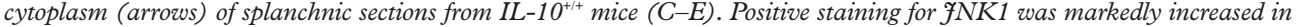
the cytoplasm (arrowheads) and nuclei (arrows) of splanchnic sections from $I L-10^{-1-}$ mice subjected to $I-R(D-F)$. Magnification $\times 1000(A-D)$ and $\times 2000(E, F)$. A similar pattern was seen in $n=5-6$ different tissue sections in each experimental group. FNK1 was identified by immunohistochemical localisation with specific antibody labelling using an avidin-biotin peroxidase technique. 

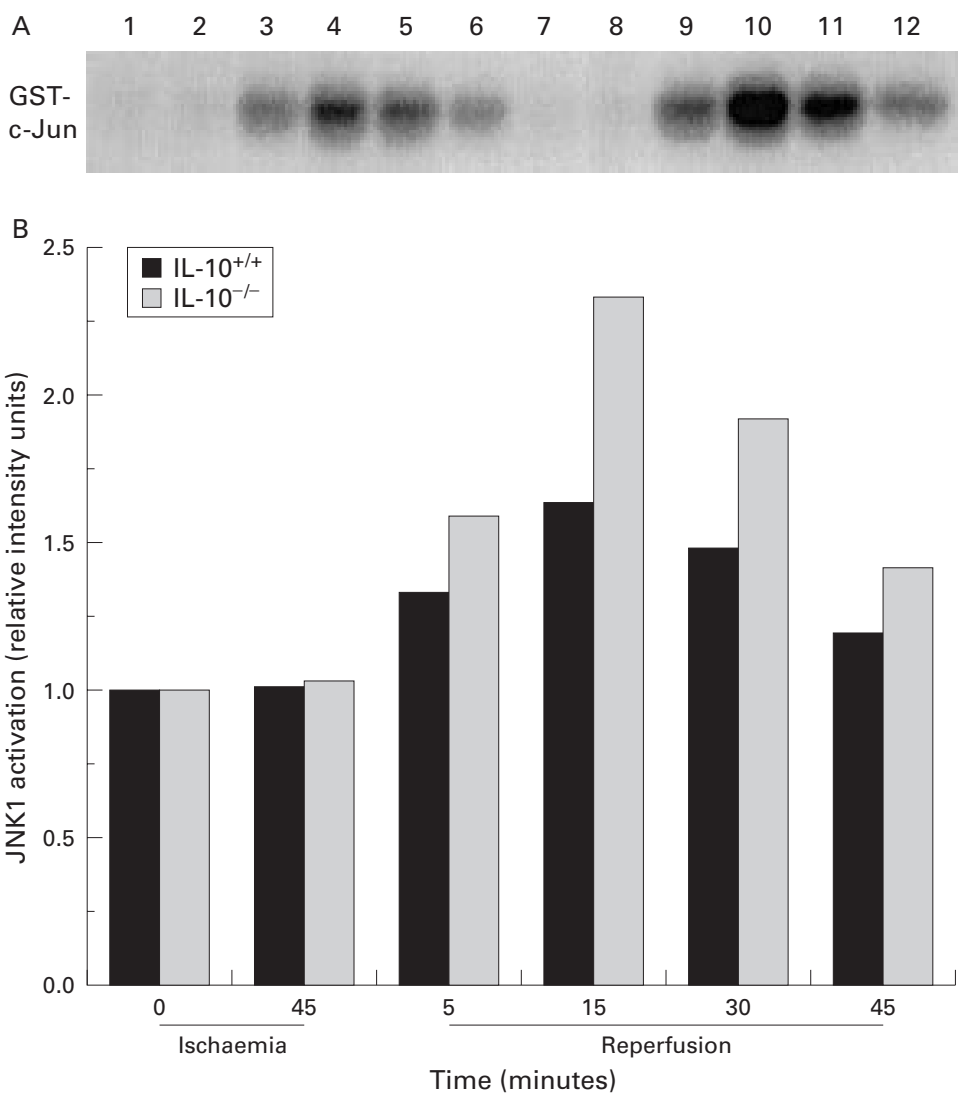

Figure 11 (A) Representative immunoblot of activation of c- $\mathfrak{f}$ un $\mathrm{NH}_{2}$ terminal kinase (FNK1) in small intestine during ischaemia (45 minutes) and reperfusion (up to 45 minutes) of the superior mesenteric artery and coeliac trunk in interleukin 10 (IL-10) ${ }^{-1-}$ and wild-type IL-10 ${ }^{+/+}$mice. Lane 1 represents intestinal basal FNK1 activity in nuclear extracts of a wild-type mouse at time 0; lanes 2-6 show FNK1 activity in splanchnic sections from wild-type mice at 45 minutes of ischaemia (lane 2), and at reperfusion at five (lane 3), 15 (lane 4), 30 (lane 5), and 45 (lane 6) minutes; lane 7 represents intestinal basal FNK1 activity of a IL-10 $10^{-1-}$ mouse at time 0; lane 8 represents $\mathcal{F N K} 1$ activity of a IL-10 ${ }^{-1-}$ mouse at 45 minutes of ischaemia; and lanes 9-12 show marked upregulation of nuclear activity at reperfusion at five (lane 9), 15 (lane 10), 30 (lane 11), and 45 (lane 12) minutes in $I L-10^{-/-}$mice. (B) Amounts of $7 N K 1$ activity (fold increase versus respective sham value set to 1.0$)$ were determined by densitometry from the immunoblot. INK1 activity was estimated as the ability to phosphorylate glutathione-S-transferase (GST)-c-fun after immunoprecipitation of nuclear proteins with specific anti-fNK1 antibody.

We found that in wild-type mice morphological and functional changes at 45 minutes of reperfusion injury were associated with increased nuclear expression of JNK1, as evaluated by immunohistochemistry (score for staining 1.45 (0.15)) (fig 10). A time course study showed that JNK1 activity increased as early as five minutes after reperfusion (fig 11 ). In $\mathrm{IL}-10^{-/-}$ mice the degree of immunostaining (score 3.40 (0.20)) and activity of JNK1 were significantly augmented in comparison with wild-type controls (figs 10, 11).

\section{Discussion}

Our data demonstrate that mice with targeted deletion of the IL-10 gene are significantly more vulnerable to death and pathological changes in the small intestine associated with ischaemia and reperfusion injury compared with wild-type controls. Thus these results suggest that the presence of a functional IL-10 gene is a major requisite to limit the magnitude and duration of splanchnic ischaemia and reperfusion injury. Furthermore, our data provide the first evidence that the stress regulated
JNK1/AP-1 signal transduction pathway is activated during splanchnic ischaemia and reperfusion and its regulation may be subject to endogenous secretion of IL-10.

IL-10 is a potent anti-inflammatory cytokine which has been shown to activate a diverse array of immunomodulatory responses. To prove the crucial role of IL-10 in controlling the inflammatory process of reperfusion injury, previous experimental studies have depended on in vivo administration of exogenous IL-10. With particular relevance to our model of mesenteric infarction, it has been reported that exogenous IL-10 limited pulmonary neutrophil recruitment and the appearance of TNF- $\alpha$ during visceral ischaemia-reperfusion injury. ${ }^{22}$ Similar therapeutic effects have been obtained with IL-10 treatment in animal models of pulmonary, hindlimb, myocardial ischaemia, and reperfusion injury and stroke. ${ }^{11223}$ In our study, using genetically engineered mice, we have demonstrated that endogenous production of IL-10 also has a notable impact in determining the outcome of reperfusion induced injury in the small intestine. Interestingly, IL-10 seems to play an obligate role during the early phase of reperfusion, as demonstrated by the fact that mice lacking a functional gene for IL-10 exhibited a high rate of mortality as early as 45-60 minutes after reperfusion.

Many pathophysiological events of mesenteric infarction may be modulated by IL- 10 . Splanchnic ischaemia and reperfusion injury is characterised by an intense inflammatory infiltrate found predominantly in the mucosa and submucosa, causing epithelial destruction by releasing reactive oxygen and nitrogen species, and cytokines. ${ }^{2-4}$ Endothelial adhesion molecules are major regulators of neutrophil traffic, regulating the process of neutrophil chemoattraction, adhesion, and emigration from the vasculature to the tissue. During the early phase of reperfusion, P-selectin is rapidly released to the endothelial surface from preformed storage pools after exposure to certain stimuli such as hydrogen peroxide, thrombin, histamine, or complement and allows the leucocytes to roll along the endothelium. ${ }^{24-26}$ ICAM-1, constitutively expressed on the surface of endothelial cells, is then involved in neutrophil adhesion. ${ }^{24}{ }^{26-28} \mathrm{We}$ observed that 45 minutes of occlusion of splanchnic arteries followed by 45 minutes of reperfusion induced the appearance of P-selectin on the endothelium of small vessels mainly in the lamina propria, and upregulated surface expression of ICAM-1 on endothelial and epithelial cells in both wild-type and IL- $10^{-/-}$mice. However, we demonstrated larger increments in expression of P-selectin and ICAM-1 in IL-10 deficient mice compared with wild-type mice at the end of reperfusion. Interestingly, we found that constitutive expression of ICAM-1 did not differ between sham IL-10 deficient and wild-type mice in the vasculature of the small intestine. Taken together with the finding of a marked reduction of the inflammatory infiltrate in wild-type mice, these data suggest that endogenous 
IL-10 does not modulate constitutive adhesion molecule expression. However, the cytokine appears to play an inhibitory role in the expression of adhesion molecules after reperfusion injury, regulating neutrophil recruitment both at the rolling and firm adhesion phases. These data are consistent with other reports demonstrating that IL-10 modulates lipopolysaccharide induced expression of ICAM-1 and VCAM-1 in the intestinal vasculature whereas it does not affect their constitutive expression. ${ }^{29}$ Other studies have also demonstrated that IL-10 has a homeostatic role on leucocyteendothelial cell interactions in response to endotoxin through regulation of endothelial adhesion molecules. ${ }^{30} 31$ Similarly, we have recently demonstrated that endogenous IL-10 protects ischaemic and reperfused myocardium through suppression of ICAM-1 expression and neutrophil recruitment. ${ }^{32}$

Leucocyte infiltration at a lesser degree in wild-type mice correlated well with moderation of post-reperfusion tissue damage, as evaluated by histological examination. Furthermore, we found that mucosal damage induced by reperfusion in IL-10 deficient mice was associated with high levels of intestinal thiobarbituric acid reactant malondialdehyde, which is considered a good indicator of lipid peroxidation. ${ }^{18} 19$ Intense immunostaining of nitrotyrosine formation also suggested that structural alteration of mucosal proteins had occurred, most probably due to formation of highly reactive nitrogen derivatives. Recent evidence indicates, in fact, that several chemical reactions, involving nitrite, peroxynitrite, hypochlorous acid, and peroxidases can induce tyrosine nitration and may contribute to tissue damage. ${ }^{33-36}$

Thus our findings suggest that the small intestine of young IL- $10^{-/}$mice is more susceptible to inflammatory stimuli such as reperfusion. Although $\mathrm{IL}-10^{-/-}$mice are used as a model of spontaneous inflammatory bowel disease, ${ }^{15}$ in the young IL- $10^{-/-}$mice used in our experiments, damage appeared to be secondary to derangement induced by reperfusion as sham mice did not exhibit histological or clinical signs of colon inflammation. In agreement with our data, it is noteworthy that deficiency of IL-10 renders mice prone to develop intestinal diseases, such as colitis, in conditions of age related stress and changes in bacterial colonisation. ${ }^{15} 37$

Several cellular mechanisms, including the mode of gene regulation and signal transduction, may account for the role of IL-10 in the modulation of splanchnic injury. In vitro and in vivo studies have reported that exogenously administered IL-10 inhibited nuclear factor $\kappa \mathrm{B}$ activation, thus suppressing proinflammatory cytokine production in human monocytes, ${ }^{38}$ development of immune complex induced lung injury in rats, and hepatic ischaemia and reperfusion in mice. ${ }^{39} 40$ Others also demonstrated that the JAK-STAT signalling pathway is required for expression of the antiinflammatory actions of IL-10 in immunostimulated macrophages. ${ }^{41}$ In the current study, we have obtained evidence that activation of JNK1 is reduced together with reduction of nuclear activation of the transcription factor AP-1 during reperfusion in the ischaemic splanchnic tissue of wild-type mice compared with IL- $10^{-/-}$mice. This suggests that endogenous IL-10 may also target the JNK1/ AP-1 signaling pathway. JNK1 phosphorylation has been observed in response to growth factors, cytokines, ischaemia, and stress signals, and has been implicated in cellular dysfunction and apoptosis of several cell types. ${ }^{5-8}$ Furthermore, it has been proposed that JNK1 activation is an important signal transduction for activation of the nuclear transcription factor AP-1 through phosphorylation of the subcomponent c-Jun. ${ }^{42}$ In this context, it is of interest that AP-1 has been implicated in regulated gene transcription of adhesion molecules in endothelium. ${ }^{43}$ Furthermore, activation of JNK1 and AP-1 has been proposed as a signalling mechanism to induce synthesis of cytokines. ${ }^{44}$ Therefore, we can speculate that the inhibitory effect of endogenous IL-10 on expression of adhesion molecules, and release of the proinflammatory cytokines IL- 6 and TNF- $\alpha$ in our model of reperfusion injury, may be due, at least in part, to suppression of the JNK1/AP-1 pathway. Whether IL-10 influences this pathway directly or indirectly deserves further investigation. We could not exclude the fact that the effect of IL-10 on JNK1 may be a result of reduced formation of oxidants and cytokines, including IL-1, IL-6, IL-8, and TNF- $\alpha^{4146}$ through other signalling pathways.

\section{Conclusions}

Our data indicate that the extent of reperfusion induced injury in the small intestine is modulated by endogenously produced IL-10, which plays a significant physiological counterbalance in the development of tissue injury. The anti-inflammatory properties of endogenous IL-10 include negative modulation of secretion of proinflammatory TNF- $\alpha$ and IL- 6 , endothelial expression of P-selectin and ICAM-1, with consequent reduction of neutrophil infiltration, and related oxidative and nitrosative stress. This anti-inflammatory effect may also be attributed to negative modulation of the cellular signalling mechanisms mediated by JNK1 and AP-1. These novel pathophysiological insights may provide a new basis for the development of tools for limiting ischaemia and reperfusion injury.

Funding for this study was provided in part by the Crohn's and Colitis Foundation of America (First Award) and by the National Institutes of Health (grant RO1 HL-60730) to Dr Basilia Zingarelli.

1 Cappell MS. Intestinal (mesenteric) vasculopathy. I. Acute superior mesenteric arteriopathy and venopathy. Gastroenterol Clin North Am 1998;27:783-825.

2 Zingarelli B, Squadrito F, Ioculano M, et al. Platelet activating factor interaction with tumor necrosis factor and myoing far mor mocardial depressant factor in splanchnic

3 Cuzzocrea S, Zingarelli B, Costantino G, et al. Beneficial effects of 3-aminobenzamide, an inhibitor of poly (ADPribocts of 3-aminobenzamide, an inhibitor of poly (ADP-
ribose) synthe in a rat model of splanchnic artery occlusion and reperfusion. Br F Pharmacol 1997;121:1065occ
74. 
4 Panes J, Granger DN. Leukocyte-endothelial cell interactions: molecular mechanisms and implications in gast

5 Gupta S, Campbell D, Derijard B, et al. Transcription factor ATF2 regulation by the JNK signal transduction pathway. Science 1995;267:389-93.

6 Mizukami Y, Yoshioka K, Morimoto S, et al. A novel mechanism of JNK1 activation. Nuclear translocation and activation of JNK1 during ischemia and reperfusion. $f$ Bio Chem 1997;272: 16657-62.

7 Onishi I, Shimizu K, Tani T, et al. JNK activation and apoptosis during ischemia-reperfusion. Transplant Proc 1999;31: 1077-9.

8 Davis RJ. Signal transduction by the c-Jun N-terminal kinase. Biochem Soc Symp 1999;64:1-12.

9 Moore KW, O'Garra A, de Waal Malefyt R, et al. Interleukin-10. Anпu Rev Immunol 1993;11:165-90.

10 Knoblach SM, Faden AI. Interleukin-10 improves outcome and alters proinflammatory cytokine expression after and alters proinflammatory cytokine expression after experim 1431 .

11 Spera PA, Ellison JA, Feuerstein GZ, et al. IL-10 reduces rat brain injury following focal stroke. Neurosci Lett 1998;251 189-92

12 Hayward R, Nossuli TO, Scalia R, et al. Cardioprotective effect of interleukin-10 in murine myocardial ischemiareperfusion. Eur F Pharmacol 1997;334:157-63.

13 Gerard C, Bruyns C, Marchant A, et al. Interleukin 10 reduces the release of tumor necrosis factor and prevents lethality in experimental endotoxemia. f Exp Med 1993; 177:547-50.

14 Daemen MA, van de Ven MW, Heineman E, et al. Involvement of endogenous interleukin-10 and tumor necrosis factor- $\alpha$ in renal ischemia-reperfusion injury. Transplantation 1999;67:792-800.

15 Kuhn R, Lohler J, Rennick D, et al. Interleukin-10-deficient mice develop chronic enterocolitis. Cell 1993;75:263-74.

16 Gudmundsson G, Bosch A, Davidson BL, et al. Interleukin-10 modulates the severity of hypersensitivity pneumonitis in mice. Am 7 Respir Cell Mol Biol 1998;19. 812-18.

17 Krawisz JE, Sharon P, Stenson WF. Quantitative assay for acute intestinal inflammation based on myeloperoxidase activity. Assessment of inflammation in rat and hamster models. Gastroenterology 1984;87:1344-50.

18 Zingarelli B, Szabó C, Salzman AL. Blockade of poly (ADP-ribose) synthetase inhibits neutrophil recruitment, oxidant generation, and mucosal injury in murine colitis. Gastroenterology 1999;116:335-45.

19 Ohkawa H, Ohishi N, Yagi K. Assay for lipid peroxides in animal tissues by thiobarbituric acid reaction. Anal Biochen 1979;95:351-8

20 Gilad E, Wong HR, Zingarelli B, et al. Melatonin inhibits expression of the inducible isoform of nitric oxide synthase in murine macrophages: role of inhibition of NF- $\mathrm{KB}$ activation. FASEB f 1998;12:685-93.

21 Arrigo AP. Gene expression and the thiol redox state. Free Radic Biol Med 1999;27:936-44.

22 Hess PJ, Seeger JM, Huber TS, et al. Exogenously administered interleukin-10 decreases pulmonary neutrophil infiltration in a tumor necrosis factor-dependent murine model of acute visceral ischemia. F Vasc Surg 1997;26:113-18.

23 Engles RE, Huber TS, Zander DS, et al. Exogenous human recombinant interleukin-10 attenuates hindlimb ischemiareperfusion injury. F Surg Res 1997;69:425-8.

24 Lawrence MB, Springer TA. Leukocytes roll on a selectin at physiologic flow rates: distinction from and prerequisite for adhesion through integrins. Cell 1991;65:859-73.

25 Davenpeck KL, Gauthier TW, Albertine KH, et al. Role of P-selectin in microvascular leukocyte-endothelial interaction in splanchnic ischemia-reperfusion. Am 7 Physiol 1994;267:H622-30.

26 Hayward R, Lefer AM. Time course of endothelialneutrophil interaction in splanchnic artery ischemiareperfusion. Am f Physiol 1998;275:H2080-6.
27 Horie Y, Wolf R, Miyasaka M, et al. Leukocyte adhesion and hepatic microvascular responses to intestinal ischemia/ reperfusion in rats. Gastroenterology 1996;111:666-73.

28 Zingarelli B, Salzman AL, Szabó C. Genetic disruption of poly (ADP-ribose) synthetase inhibits the expression of P-selectin and intercellular adhesion molecule-1 in myocardial ischemia-reperfusion injury. Circ Res 1998;83:8594.

29 Morise Z, Eppihimer M, Granger DN, et al. Effects of lipopolysaccharide on endothelial cell adhesion molecule expression in interleukin-10 deficient mice. Inflammation 1999;23:99-110.

30 Santucci L, Fiorucci S, Chiorean M, et al. Interleukin 10 reduces lethality and hepatic injury induced by lipopolysaccharide in galactosamine-sensitized mice. Gastroenterology 1996;111:736-44.

31 Hickey MJ, Issekutz AC, Reinhardt PH. Endogenous interleukin-10 regulates hemodynamic parameters, leukocyte-endothelial cell interactions, and microvascular permeability during endotoxemia. Circ Res 1998;83:112431.

32 Yang Z, Zingarelli B, Szabó C. Crucial role of endogenous interleukin-10 production in myocardial ischemia/ reperfusion injury. Circulation 2000;101:1019-26.

33 Beckman JS. Oxidative damage and tyrosine nitration from peroxynitrite. Chem Res Toxicol 1996;9:836-44.

34 Eiserich JP, Cross CE, Jones AD, et al. Formation of nitrating and chlorinating species by reaction of nitrite with hypochlorous acid. A novel mechanism for nitric oxidemediated protein modification. F Biol Chem 1996;271: 19199-208.

35 Eiserich JP, Hristova M, Cross CE, et al. Formation of nitric oxide derivatives catalysed by myeloperoxidase in neutrophils. Nature 1998;391:393-7.

36 Halliwell $\mathrm{B}$. What nitrates tyrosine? Is nitrotyrosine specific as a biomarker of peroxynitrite formation in vivo? FEBS Lett 1997;411:157-60

37 Madsen KL, Doyle JS, Jewell LD, et al. Lactobacillus species prevents colitis in interleukin 10 gene-deficient mice. Gastroenterology 1999;116:1107-14.

38 Wang P, Wu P, Siegel MI, et al. Interleukin (IL)-10 inhibits nuclear factor $\kappa \mathrm{B}(\mathrm{NF}-\kappa \mathrm{B})$ activation in human monocytes. IL-10 and IL- 4 suppress cytokine synthesis by different mechanisms. F Biol Chem 1995;270:9558-63.

39 Lentsch AB, Shanley TP, Sarma V, et al. In vivo suppression of NF- $\kappa B$ and preservation of $I \kappa B \alpha$ by interleukin- 10 and interleukin-13. F Clin Invest 1997;100:2443-8.

40 Yoshidome H, Kato A, Edwards MJ, et al. Interleukin-10 suppresses hepatic ischemia/reperfusion injury in mice: implications of a central role for nuclear factor $\kappa \mathrm{B}$. Hepatology 1999;30:203-8.

41 Riley JK, Takeda K, Akira S, et al. Interleukin-10 receptor signaling through the JAK-STAT pathway. Requirement for two distinct receptor-derived signals for antiinflammatory action. $\mathcal{F}$ Biol Chem 1999;274:16513-21.

42 Karin M, Liu Zg, Zandi E. AP-1 function and regulation. Curr Opin Cell Biol 1997;9:240-6.

43 Roebuck KA, Rahman A, Lakshminarayanan V, et al. $\mathrm{H}_{2} \mathrm{O}_{2}$ and tumor necrosis factor- $\alpha$ activate intercellular adhesion molecule 1 (ICAM-1) gene transcription through distinct cis-regulatory elements within the ICAM-1 promoter. $\mathcal{f}$ Biol Chem 1995;270:18966-74

44 Mesri M, Altieri DC. Leukocyte microparticles stimulate endothelial cell cytokine release and tissue factor induction in a JNK1 signaling pathway. $\mathcal{F}$ Biol Chem 1999;274:2311118.

45 Song JS, Haleem-Smith H, Arudchandran R, et al. Tyrosine phosphorylation of Vav stimulates IL-6 production in mast cells by a Rac/c-Jun $\mathrm{N}$-terminal kinase-dependent pathway. f Immunol 1999;163:802-10.

46 Bogdan C, Vodovotz Y, Nathan C. Macrophage deactivation by interleukin 10. F Exp Med 1991;174:1549-55. 